\title{
The role of heads of departments in the commercialization of university research
}

\author{
Karl-Heinz Leitner $^{1,2} \cdot$ Sabine Bergner ${ }^{1} \cdot$ Robert Rybnicek $^{1}$ (우
}

Published online: 27 July 2020

(C) The Author(s) 2020

\begin{abstract}
The commercialization of knowledge has become increasingly important for universities worldwide. Today, the acquisition of third-party funds, the filing of patents and the foundation of spin-offs are seen as similarly relevant to other academic activities such as conducting research and teaching. Research has examined how universities can be supported in their transformation into entrepreneurial institutions and shown that the business experience of scientists might foster the commercialization of knowledge. However, research into the role of academic leaders in this process is scant. In this study, we examine how far the business and scientific experience of the head of department impacts the entrepreneurial activities of an entire department team. Our results demonstrate that heads with business experiences positively influence the acquisition of third-party funds and the patent output of the whole department. However, we found that the foundation of spin-offs is negatively affected by these experiences. Our findings have important policy implications and suggest that business experiences should be considered in the assignment of new heads when reorienting universities into entrepreneurial institutions and restructuring university funding. Yet, the business experience of academic leaders is not a panacea and has its limitations.
\end{abstract}

Keywords Entrepreneurial university · University-industry collaboration · Thirdparty funds $\cdot$ Patents $\cdot$ Spin-offs $\cdot$ Business experience

JEL Classification I23 $\cdot \mathrm{O} 32 \cdot \mathrm{O} 380$

Robert Rybnicek

robert.rybnicek@uni-graz.at

1 Department of Corporate Leadership and Entrepreneurship, University of Graz, Elisabethstrasse 50b/2, 8010 Graz, Austria

2 Center for Innovation Systems \& Policy, AIT Austrian Institute of Technology, Giefinggasse 4, 1210 Vienna, Austria 


\section{Introduction}

The commercialization of knowledge has become increasingly important for universities worldwide. Concepts and theories like the entrepreneurial university (Etzkowitz 2003), the third mission of universities (Pinheiro et al. 2015; Zomer and Benneworth 2011) and the Triple-Helix (Etzkowitz and Leydesdorff 2000) have been proposed to progressively transform universities into entrepreneurial institutions. These entrepreneurial universities are closely linked to the demands of industry, society and governments (Etzkowitz 2016) and are strongly advised to diversify their funding streams (Slaughter and Leslie 2001; Tijssen 2006). A further reason for this development is the decreasing willingness to publicly finance universities due to scarce governmental resources and a continuous increase in student numbers. Universities responded to this challenge by implementing management tools primarily used in the private sector (Peus et al. 2015) to increase efficiency (e.g. new public management; Leisytë and Kizniene 2006) and further attempted to unlock additional financial facilities by actively promoting and commercializing their knowledge.

In fact, all those approaches and theories demand a tremendous change in the mindset of the university members and policymakers. In addition to teaching and research, entrepreneurial activities come to the fore. Truth-seeking academics need to evolve into entrepreneurial actors capable of considering the practical implications of their research and matching their knowledge with the needs of external partners (Elia et al. 2017; Etzkowitz and Viale 2010). The questions arise how universities can successfully master this paradigm shift from a mere scientific institution to an entrepreneurial university and how they can motivate research teams to adapt their behaviour in that new direction.

Regarding the research performance of scientists, numerous findings emphasize the role of leaders at universities. Goodall, for example, proved in several studies that the scientific experiences and competences of academic leaders enhance the scientific performance of their teams and institutions in the future (Goodall 2006, 2009; Goodall et al. 2014). However, today's universities are no longer just research institutions. They behave like 'firms' and need to provide their research outcomes to a 'market' where 'customers' like funding agencies or private firms can buy these outcomes in return for funding (Etzkowitz 2003; Ziman 1995).

Hence, if the scientific experience of academic leaders constitutes the research performance of their research teams, labs or departments, what characteristics are the premise for the success of an entrepreneurial university? There is reason to assume that modern academic leaders must have both scientific and business experience to counter the new requirements of entrepreneurial universities. However, research in this regard is scant as previous studies for the most part did not focus on team-level performances but mainly investigated whether the business experience of individual researchers themselves inhibits or facilitates their own scientific or entrepreneurial activities. Therefore, we take a closer look at the question of how far previous scientific and business experiences of academic 
leaders impact the entrepreneurial performance of their entire research team. To be more precise, we seek to identify how these specific experiences influence the department's capability to raise third-party funds, generate patents and establish spin-offs.

To examine this relationship, we captured data from 219 academic leaders in the natural and technical sciences in Austria and matched this information with the entrepreneurial activities of the research team. Austria is an interesting case to study as many universities have adopted entrepreneurial strategies in the last decade, which has also been stimulated by the national research and education policy (BMBWF 2018). We combined data from different sources. Data about the academic leaders (i.e. the heads of departments) came from their CVs and the commercial register. Data about the departments' research team were taken from the biannual survey by Statistics Austria as well as the universities' internal publication and patent databases. Finally, we conducted logistic and negative binomial regression analyses to test our hypotheses and to determine the importance of our variables.

The results show a positive relationship between business experiences of heads and third-party funds of the departments. Furthermore, we found that both scientific experiences and business experiences positively influence the patent output. However, regarding the creation of spin-offs, only the scientific experiences had a positive impact, while business experience surprisingly had a negative one. Our findings have important policy implications and suggest that business experiences should be considered in the assignment of new professors when reorienting universities into entrepreneurial institutions and restructuring university funding. Yet, the business experience of academic leaders is not a panacea and has its limitations, particularly when transferring scientific knowledge into an actual business idea.

We contribute to the literature by developing a theoretical model regarding academic entrepreneurial activities and by thoroughly investigating the relationship of different forms of experiences of academic leaders on those activities. This enhances the understanding of mechanisms underlying entrepreneurial universities and helps policymakers to develop an adequate environment in which to foster universities' entrepreneurial activities.

In the next section, we review the relevant literature, develop our theoretical model and propose testable hypotheses. In Sect. 3, we describe the methods and data used, before we present our results in Sect. 4. In Sect. 5, we discuss the main results in the context of the literature and highlight implications for academia and practice.

\section{Theoretical background and hypotheses development}

Our research question consists of two elements-the entrepreneurial activities of the departments (see Sect. 2.1) and the experiences of the heads (see Sect. 2.2). Subsequently, we discuss the relevant literature of those elements before we combine them to derive our hypotheses in Sect. 2.3. 


\subsection{Entrepreneurial activities of departments}

In contrast to traditional universities, entrepreneurial universities do not only foster teaching and research but also cope with societal and economical needs-in other words, they deliver on their third missions (Jones et al. 2013). For this purpose, entrepreneurial universities have to promote an entrepreneurial culture, stimulate relationships with industry and integrate managerial and market-related tools (Tijssen 2006). Consequently, their members often need to collaborate with partners from industry and government to mutually develop new knowledge and commercialize it (Elia et al. 2017).

However, what exactly do we understand when we speak about the collaboration with external partners and the commercialization of knowledge? Perkmann et al. (2013) differ in their systematic literature review on university - industry relations between academic engagement and commercialization. They define academic engagement as knowledge-related collaboration of academic researchers with nonacademic institutions, including contract research, consulting, and more informal activities like simple ad hoc advice and networking. Commercialization, in turn, is predominantly about exploiting academic inventions and reaping financial rewards through patenting, licensing or founding academic spin-offs (Perkmann et al. 2013).

Another distinction was developed by Etzkowitz (2016), who includes a chronological perspective and differs between three phases of academic entrepreneurship: in an initial phase, universities start to set their own priorities and to raise their own resources; in the second phase, they actively commercialize their knowledge and intellectual property; and in the third phase, universities seek to take a proactive and strategic role in developing the innovative potential in their region, for example, through the spin-off of new firms.

If we combine the classifications of Perkmann et al. (2013) and Etzkowitz (2016) we can distinguish between commercialization in a narrow sense, which is about actually selling scientific results and generating additional income, and commercialization in a broad sense, which also includes actively promoting scientific results and making them available and applicable to a (non-scientific) market. We obtain a continuum of entrepreneurial academic activities with different degrees of commercialization. As depicted in Fig. 1, on the one side of this continuum, informal activities like networking or ad hoc advice for industry partners are located, while on the other side the founding of actual companies to make money is located.

In this article, we focus on those entrepreneurial academic activities that are encompassed by Etzkowitz's (2016) three phases of academic entrepreneurship, since these activities are relevant indicators for the entrepreneurial development of a university. In fact, the acquisition of third-party funds, the filing of patents and the foundation of spin-offs have become important criteria for the careers of researchers and academic leaders. However, many researchers have raised profound concerns about these developments and questioned the increasing dominance of entrepreneurial approaches and goals at universities. For example, Subotzky (1999) discuss that the focus on market demands influences research and teaching priorities to orient more towards commercializable disciplines and issues (e.g. science and technology versus social sciences and humanities, applied research and short-term orientation 


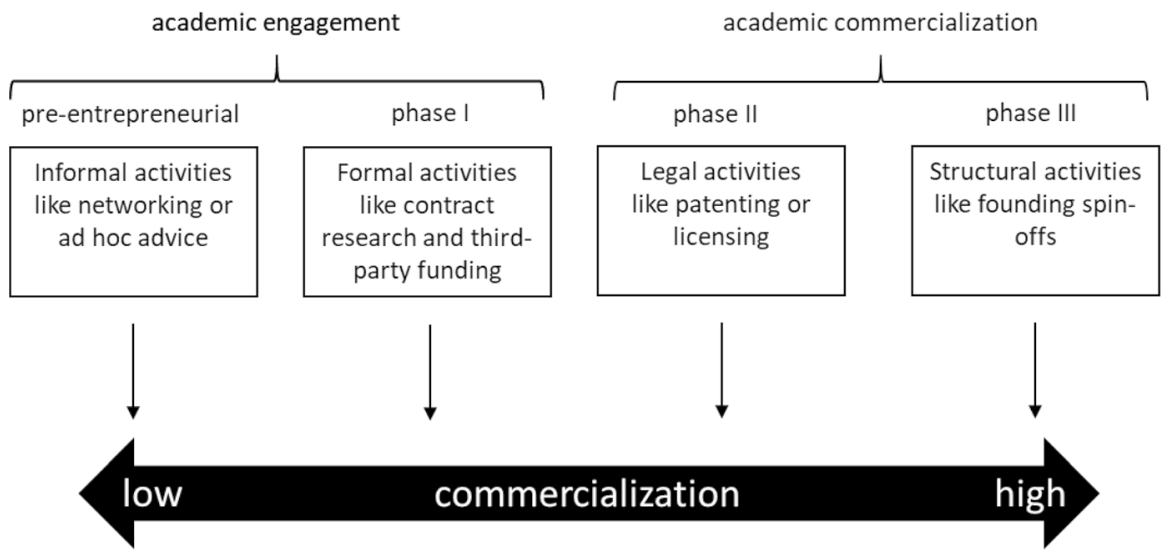

Fig. 1 Continuum of entrepreneurial academic activities. Classifications are based on Perkmann et al. (2013) and Etzkowitz (2016)

versus basic research and long-term orientation). This bears the risk of tremendous consequences on organizational culture, funding, faculty behaviour or scientific practices (Subotzky 1999). There is also a rich debate on whether entrepreneurial activities and industrial engagement have a negative impact on the research productivity of researchers. While some authors find that faculties with industrial support publish at least as many scientific articles as their colleagues (e.g. Gulbrandsen and Smeby 2005), others report that researchers publish less over their career as a whole (Lin and Bozeman 2006). Furthermore, it is also argued that universities might lose some of their autonomy due to increasing corporate influence and dependency on additionally acquired resources (Armbruster 2008; Subotzky 1999). Another critical aspect is brought up by Goddard et al. (2012), who state that entrepreneurial universities may focus too strongly on the regional issues, economies and innovation systems, which, however, should not be the primary interest of an international university. Concluding, the aim to become an entrepreneurial university has many downsides and inherent risks and is not a generic strategy that can and should be adopted by all universities.

\subsection{Experiences of the heads of departments}

Many universities have taken various actions among students (Packham et al. 2010; Secundo et al. 2017) and staff members to raise awareness of the demands of entrepreneurial universities. Today's universities need scientists that live the entrepreneurial spirit and embrace change (van Vught 1999). However, how can universities foster this spirit and who is capable of initiating this shift?

To answer this question, we have to bear in mind that universities are considered as professional organizations (as defined by Mintzberg 1980). The formal and informal power in these organizations is mainly located in the operating units (in our case the departments), where the professionals (in our case the scientists) work relatively freely of the administrative hierarchy and autonomously of other colleagues 
(Mintzberg 1980). Consequently, 'strategic' demands of distant policymakers, politicians or administrative personnel are unlikely to be successfully realized if they do not find the support of the professionals themselves. To find this support and to initiate organizational change, a leader must be, in fact, an expert oneself (Mintzberg 1980).

In other words, if scientists are required to 'act more entrepreneurially', the leaders who are best equipped to successfully manage this shift must be credible in both scientific as well as entrepreneurial matters. Based on these considerations, we assume that the heads of departments are those individuals who are close enough to be accepted as experts and consequently are capable of initiating change by providing a good example. In particular, when implementing changes and merging the individual scientific autonomy with new organizational needs, the heads of departments play a crucial role (Bergner 2015). Similarly to the private sector, they are responsible for the actual transformation, have to develop plans accordingly, must provide resources and should motivate staff (Peus et al. 2015). And, of course, today they increasingly have to merge scientific capabilities with business-oriented and market-driven forces (Tijssen 2006).

Therefore, to set a pattern for the scientific and business performance of their research team, the heads of departments must yield two abilities: first, scientific experiences as the essential basis to create new knowledge and inventions; and second, business experiences to properly evaluate the commercial potential of new findings. In the remainder of this section, we take a closer look at those competences before deriving our hypotheses.

\subsubsection{Scientific experiences of heads of departments}

Generally, experience refers to an individual's previous exposure to domain-specific roles and activities (Dragoni et al. 2011). Scientific experience, in particular, denotes existing practical knowledge, skill or practice derived from direct participation in scientific activities. Such scientific activities are, for example, designing and executing scientific studies or publishing research results. The latter, in particular, often serves as proxy for the capabilities and scientific experiences of researchers, for which reason it is considered as one of the most relevant key performance indicators in the scientific community and included in many well-known university rankings (Aguillo et al. 2010; Buela-Casal et al. 2007). The aggregated number of publications is also often associated with research productivity (Gonzalez-Brambila and Veloso 2007). Moreover, publications are known to be an important way of communicating with industry partners as they allow companies to identify areas of expertise within universities (Arundel and Geuna 2004; Gonzalez-Brambila and Veloso 2007).

There exists multiple evidence that the scientific experiences of heads of departments impact the scientific performance of subordinate scientists and research teams. Most notably, Goodall performed several investigations in that context, which all demonstrated the important role of the scientific abilities and experiences of academic leaders in the research performance of their institutions in later decades (Goodall 2006, 2009; Goodall et al. 2014). These results are in accordance with 
Mintzberg's (1980) 'professional organizations', where leaders must themselves be acknowledged experts in their field in order to have power and to maintain the support of the professionals.

However, the impact of the scientific experience of leaders on the entrepreneurial performance of departments is less investigated as recent studies mainly focus on scientists in general and not on leaders. Nevertheless, these studies allow important conclusions for our research questions too, namely that there is a relationship between scientific experience and entrepreneurial activities. There exists a considerable body of literature investigating which researchers are most likely to be involved in entrepreneurial activities and in how far these activities positively or negatively influence their research and teaching performance. Some authors, for example, argue that scientists worry that the collaboration with industry might impact their academic productivity and career. For example, Lee (1996) found that especially scientists in top universities fear negative consequences resulting from too close an industry - university collaboration as it might interfere with their core values education, research and integrity. Consequently, this might result in a negative relationship between scientific experience and entrepreneurial activities. Gulbrandsen and Smeby (2005), in turn, found neither a positive nor a negative relationship and a number of studies showed a mainly positive relationship between research performance and entrepreneurial activities: in their literature analysis, Perkmann et al. (2011) come to the conclusion that, generally speaking, scientists with a higher publication output also excel at patenting and academic entrepreneurship. However, they also assert that the relationship between research quality and different forms of entrepreneurial activities — see our continuum of academic entrepreneurial activities in Fig. 1-might vary and need more research.

Taken together, literature largely suggests a positive relationship between the scientific experience of scientists and different kinds of entrepreneurial activities. However, there is less evidence regarding to what extent the experience of the head of department impacts on the entrepreneurial output. Therefore, in this study we address this gap by examining the scientific experiences of heads in relation to a broad spectrum of academic entrepreneurial activities, namely third-party funds, patents and spin-offs.

\subsubsection{Business experiences of heads of departments}

In a similar vein to scientific experience, business experience is understood as existing practical knowledge, skill or practice derived from direct participation in business activities. Such business activities include, for example, founding and owning a firm, holding management positions, or working in industry in general (see, for example, Lin and Bozeman 2006). In entrepreneurship research, previous work experience has received much attention as it has been found to influence different kinds of business-relevant activities, such as the recognition of opportunities (Shane 2000), the generation of new business ideas (Gabrielsson and Politis 2012) or the intention to start a business (Kim et al. 2006; Zapkau et al. 2015).

Generally, business experiences should help to properly evaluate the commercial potential of new findings, support trust-building measures in collaboration with 
non-academic partners and help to establish a cooperative culture and mutual language. Therefore, it is not surprising that scholars found evidence suggesting a positive relationship between the business experience of researchers and different kinds of entrepreneurial activities. In their study of Norwegian professors, Gulbrandsen and Smeby (2005), for instance, revealed that academics with strong relationships with industry report more frequent entrepreneurial results (e.g. patents, spin-off companies and involvement in consulting work). In another study by Dietz and Bozeman (2005) it was shown that business experiences in industry had a strong positive impact on the patent productivity of scientists. They argue that the intersectoral changes in jobs provide access to new social networks, therefore suggesting an indirect effect. Consequently, Siegel et al. (2003) recommend that universities that wish to foster commercialization need to encourage informal relationships and social networks. In this context, it is assumed that more diversity in work experience facilitates the building of new competencies and skills, fosters networks and relationships, enables access to knowledge gatekeepers and increases productivity as a result thereof (see the 'diversity hypothesis' as discussed in Dietz and Bozeman 2005).

Summing up, there is reasonable evidence that the business experience of scientists directly and indirectly impacts their entrepreneurial activities. Unfortunately, research is mostly silent on whether the business experience of heads of departments have similar effects. Harvey et al. (2002) emphasize that leaders of successful research groups, in general, are central to generating funding, providing access to their social network and establishing an entrepreneurial environment. Moreover, the authors assert that today's leaders face a more business-oriented environment and therefore the skills needed to be an effective leader have changed.

Based on the existing literature, we claim that business experience positively relates to different kinds of entrepreneurial activities. Similarly to the previous subsection, we assume that the heads of departments play a crucial role in this matter. However, again, relevant evidence is missing, which is why we address this issue and examine the relationship between the business experience of heads of departments and the entrepreneurial performance of their departments (i.e. third-party funds, patents and spin-offs).

\subsection{This study}

In the previous two subsections, we reviewed the literature on entrepreneurial activities of universities and the impact of scientific and business experiences on these activities. We first developed the continuum of entrepreneurial academic activities (see Fig. 1, Sect. 2.1), depicting different degrees of commercialization of these activities. We then decided to focus our study on third-party funds, patents and spinoffs, as they are, according to Etzkowitz (2016), particularly relevant indicators for the entrepreneurial development of a university. Subsequently, we saw that scientific and business experiences of scientists can increase their entrepreneurial activities. However, what is not yet clear is the role of heads of departments and the question of to what extent these heads can influence the development of their team's 
entrepreneurial activities and whether their scientific or business experiences influence the performance in that regard.

Based on the assumptions of Mintzberg (1980), we suggest that heads of departments must be experts in those areas they demand from their subordinates. Hence, if heads require individual team members or their entire team to enhance entrepreneurial activities, we claim that business-related experiences of the leaders come to the fore and therefore assume that third-party funding, patent output and spin-offs are positively influenced by said experiences. To complete our research setting, we also test how important the scientific experience of heads is in this context, as we assume that their scientific abilities are essential to creating new knowledge and inventions. Combining these considerations, we suggest the following hypotheses:

- Third-party funding

o Hypothesis 1a: Business experience of heads of departments has a positive impact on the level of private third-party funding.

o Hypothesis 1b: Scientific experience of heads of departments has a positive impact on the level of private third-party funding.

- Patent output

o Hypothesis 2a: Business experience of heads of departments has a positive impact on the patent output.

o Hypothesis 2b: Scientific experience of heads of departments has a positive impact on the patent output.

- Spin-offs

o Hypothesis 3a: Business experience of heads of departments has a positive impact on the creation of spin-offs.

o Hypothesis 3b: Scientific experience of heads of departments has a positive impact on the creation of spin-offs.

Our conceptual model, which comprises the continuum of academic entrepreneurial activities and relates them to the hypotheses discussed above, is depicted in Fig. 2.

\section{Methods and data}

\subsection{Sample}

This study is part of a larger research project investigating different drivers of entrepreneurial activities at universities and is based on a sample of 219 university 
academic engagement

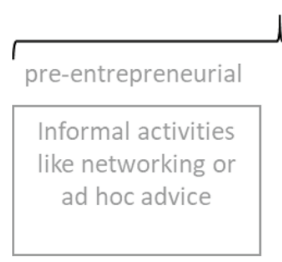

1
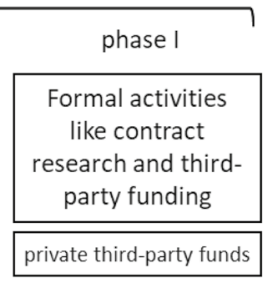
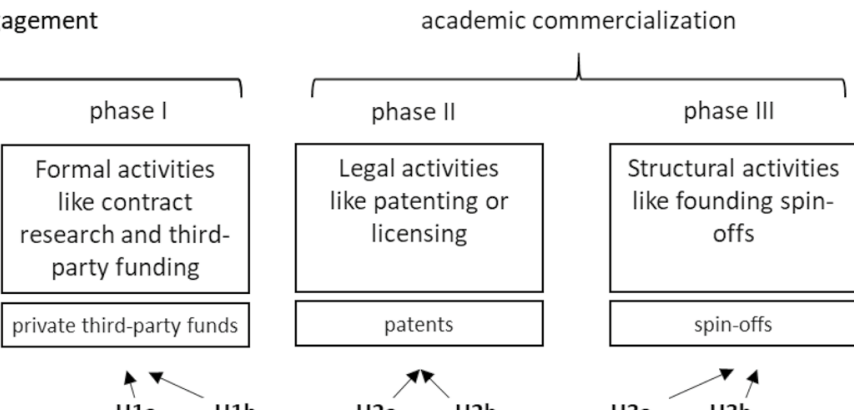

academic commercialization

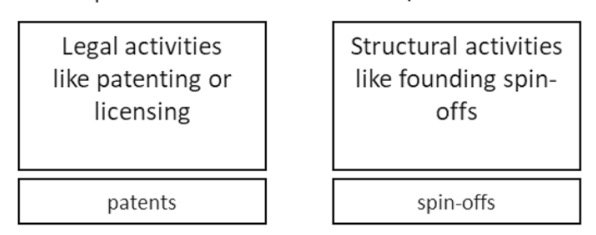

Business experience

of the head of department

Scientific experience of the head of department

Fig. 2 Conceptual model

departments in natural and technical sciences from 10 public Austrian universities ${ }^{1}$. We decided to focus on these disciplines as in both fields external funding has grown considerably in the last two decades and nowadays plays a crucial role (BMBWF 2018), suggesting reciprocal interest in the collaboration between industry and university departments. In terms of the organizational and governance structure of Austrian universities, departments can be considered as relevant units of observation. These departments have a large autonomy, are requested to strategically steer development and typically have 20-40 employees. The faculties or schools of the universities are usually too big and heterogeneous to compare them and to analyse the impact of various input variables on the output.

We considered the development of the departments over a period of three years between 2013 and 2015 and selected those departments that had the same head of department over this period of time, which was the case for $77 \%$ of a total of 270 natural and technical sciences departments from the 10 universities. As the turnover is rather small, we did not take into account those departments that changed their heads. In Austria, the recruitment of the heads of departments is the responsibility of the universities. There exist no laws or governmental rules about the required

\footnotetext{
${ }^{1}$ University of Vienna, University of Graz, University of Innsbruck, University of Salzburg, Vienna University of Technology, Graz University of Technology, Montanuniversität Leoben, University of Natural Resources and Life Sciences of Vienna, University of Linz, University of Klagenfurt.
} 
qualifications of heads, so the universities can determine their own rules. However, today many universities consider leadership or business experience in the appointment of professors (e.g. Vienna University of Technology, University of Graz), following the trend that already integrates these qualifications and experiences in the job specifications of a professorship (Rybnicek et al. 2016).

\subsection{Data collection and measurement}

We collected data from various sources to determine our dependent and independent variables. A complete list of these variables, including their source, can be found in Appendix A.

Regarding the heads of departments, the measurement business experience covered different qualifications from the CVs and the commercial register. We analysed CVs on the department webpages but also on additional Internet sites in order to ensure up-to-date CVs. For the analyses, we developed a coding system to collect data regarding business experience (excluding positions at universities, non-governmental organizations and public institutions). Additionally, we included data from the Austrian commercial register to check whether heads of departments have served as managing directors, owners, supervisory board members or authorized representatives of a company. In this context, we analysed the type and duration of position. For the subgroup, for which we were able to collect the exact number of years, we additionally ran all relevant statistical tests. These tests delivered no evidence of different results or a specific effect of the length of business experience and hence we finally used a dummy variable for measuring business experience. In addition, we identified the age of the heads of departments, which served as control variable. The scientific experience was assessed by the scientific publication output of the heads of departments. We used the reporting system for Austrian universities, which is defined by law, and collected data from the public research portals of the universities. We developed a measure encompassing articles in journals, monographs, edited books and proceedings and used full counting. We collected the number of total publications for the heads of departments for the years 2013-2015 and calculated the mean. We then calculated a dichotomous variable with those heads that belong to the top $25 \%$ in terms of the publication output, investigating the impact of the top performers. We normalized the number of publications taking into account the discipline.

Regarding the entrepreneurial activities of the departments, the measurement private third-party funding was derived from R\&D expenditures survey conducted biannually by Statistics Austria. We used the data of the 2013 and 2015 surveys and calculated the mean for the 3 -year period. This survey is obligatory for all university departments and collects data about the departments, their heads, scientific disciplines, research foci, the number of scientific team members of the department (measured as full-time equivalent) and additional characteristics such as length of employment and education, R\&D expenditures and origin of financial resources (for more information about the survey see Statistics Austria 2017). We used the amount of private third-party funding as a percentage of the total funding and generated 
three groups: group 1: no private third-party funding (25\% of all departments); group 2: between 0 and $15 \%$ third-party funding (50\% of all departments); group 3: above $15 \%$ private third-party funding ( $25 \%$ of all departments). Third-party private funds cover funds from private organizations, with enterprises being the most important source. The number of patents is disclosed by the internal reporting system for Austrian universities (see the previous paragraph) and we used the total number of patents granted to team members of the department between 2013 and 2015. To collect data about the created spin-offs we contacted the departments by mail and phone. We counted all spin-offs where at least one scientist of the department was involved as a founder.

\subsection{Data analysis}

Considering the different types of variables, we conducted logistic and negative binomial regression analyses. As the private third-party funds did not meet the assumption of normality to conduct an OLS regression, we hence used a binary variable, distinguishing the top $25 \%$ from the remaining rest and employing a logistic regression. In addition, the number of patents, which served as dependent variable in one hypothesis test, had a highly skewed count data and revealed overdispersion. We thus ran a negative binomial regression model for studying the patent output. The variables location (Vienna), discipline (technical sciences), type of university (technical university), publication performance of the head of department (top group) and business experience were binary variables coded with 0 (without the defining characteristic) and 1 (with the characteristic). For the dependent variable spin-off we used a dichotomous variable indicating whether the department generated no or at least one spin-off between 2013 and 2015. When integrating these dichotomous independent variables in the logistic regression and negative binomial regression models, the first category coded as 0 served as reference group. The list of all variables and their description can be found in Appendix A. We controlled for size, discipline and age, which should have an impact on the output, according to the literature (e.g. Carayol and Matt 2006; Fabel et al. 2008). For the variable age, we also calculated the squared value in order to control for any possible non-linear effects (Bolli and Somogyi 2011). In addition, we used the location of the university (=Vienna) as control, took into account the discipline (natural science versus technical sciences) and checked whether the departments belong to a technical university. In order to differentiate between the disciplines, we used the 'Austrian Systematics of the Sciences' (Statistics Austria 2013). Natural sciences cover six subfields (e.g. mathematics, physics, biology) and technical sciences cover eleven subfields (e.g. construction, mechanical engineering, electrical engineering). 
Table 1 Dependent variable: private third-party funds of the department 2013-2015 (top $25 \%)$, logistic regression

\begin{tabular}{llll}
\hline Independent & $\mathrm{B}$ & $\operatorname{Exp}(\mathrm{B})$ & $\mathrm{p}$ \\
\hline Constant & 6.600 & & 0.453 \\
Scientific experience of the head & 0.503 & 1.654 & 0.314 \\
Business experience of the head & 1.039 & 0.354 & 0.018 \\
Size & 0.023 & 1.024 & 0.103 \\
Technical sciences & 2.192 & 0.112 & 0.000 \\
Technical university & 0.171 & 0.843 & 0.730 \\
Vienna & -1.424 & 4.154 & 0.007 \\
Age & -0.307 & 0.736 & 0.350 \\
Age squared & 0.003 & 1.003 & 0.376 \\
N & 219 & & \\
Chi-square & 54.023 & & 0.000 \\
Log-likelihood & 165.707 & & \\
\hline
\end{tabular}

\section{Results}

Descriptive statistics for the variables used in the study, including means, standard deviation and correlation, are provided in the Appendix. With regard to our main variables of interest, the business experience, the data revealed that among the 219 heads of departments, 103 had prior business experience. Fifty-six heads of departments belonged to the top $25 \%$ group in relation to their publication output. Fiftyseven departments had published at least one patent and 28 departments had created at least one spin-off between 2013 and 2015. Overall, 105 departments were engaged in natural sciences and 114 departments belonged to technical sciences and engineering. A total of 135 departments belonged to 1 of the 3 technical universities and 79 departments were part of the three universities in Vienna.

\subsection{Private third-party funding}

To test hypotheses $1 \mathrm{a}$ and $1 \mathrm{~b}$ dealing with the effect of business experience and scientific experience on private third-party funding, we conducted a regression model with the share of private third-party funds (Table 1). As the private thirdparty funding variable was skewed and did not meet the requirements to run an OLS regression, we conducted a logistic regression, splitting the departments into two groups. We compared the departments that had private third-party funding belonging to the top $25 \%$ group, which had more than $15 \%$ of the total research funding financed by third-party funds, with the reference group. We were particularly interested in explaining the determinant for the success of the top performing departments and thus cut at $25 \%$. Table 1 depicts the results of this analysis. We found a positive coefficient for the effect of business experience on private third-party funding $(b=1.039)$. The scientific experience of the department head had no significant impact on the extent of acquiring private funds. The discipline explains the level 
Table 2 Dependent variable: patents 2013-2015, negative binomial regression model

\begin{tabular}{llll}
\hline Independent & $\mathrm{B}$ & $\mathrm{Exp}(\mathrm{B})$ & $\mathrm{p}$ \\
\hline Constant & -15.754 & & 0.016 \\
Scientific experience of the head & 1.193 & 0.303 & 0.000 \\
Business experience of the head & 0.599 & 0.549 & 0.014 \\
Size & 0.049 & 1.050 & 0.000 \\
Technical sciences & 0.248 & 0.780 & 0.346 \\
Technical university & -0.959 & 2.609 & 0.000 \\
Vienna & -0.428 & 1.534 & 0.116 \\
Age & -0.635 & 1.888 & 0.009 \\
Age squared & -0.006 & 0.994 & 0.005 \\
N & 211 & & \\
Likelihood-Ratio Chi-square & 153.372 & & 0.000 \\
\hline
\end{tabular}

of private third-party funding $(b=2.192)$, showing that technical sciences and engineering departments have higher levels thereof. In contrast, size, age of the head of department and type of university had no significant effect. Universities in Vienna have lower levels of third-party funds $(b=-1.424)$, which is partly explained by a lower share of industrial companies located in Vienna. Thus, we found support for hypothesis $1 a$, but had to reject hypothesis $1 b$.

We further analysed the data by conducting a nominal regression model with three categories of the independent variable private third-party funding: group 1: no private third-party funding (25\% of all departments); group 2: between 0 and $15 \%$ third-party funding (50\% of all departments); group 3: above 15\% private third-party funding ( $25 \%$ of all departments). This model revealed that business experience has a positive significant effect on the extent of private third-party funding when comparing those departments that have no private funds at all with the medium and top private-funding group (not shown here). The coefficient was stronger for the top performing group. Thus, among the group of departments that have not acquired any private external funds, heads of departments are more likely to not have any business experience either. The scientific experience of the department chair had no impact in any comparison of groups tested.

\subsection{Patent output}

Due to the nature of the dependent variable number of patents, which was skewed, we ran a negative binomial regression model to investigate potential predictors of a department's patent output (Hypotheses $2 \mathrm{a}$ and $2 \mathrm{~b}$ ). Table 2 depicts the results with the main effect variables and control factors. The regression analysis shows that business experience had positive coefficients $(b=0.599)$. Thus, departments with more experienced heads are more likely to publish patents, which provides support for our hypothesis $2 a$. The scientific experience was positively correlated with the patent output of departments, revealing that the top-experienced heads of 
Table 3 Dependent variable: spin-offs of the department 2013-2015, logistic regression

\begin{tabular}{llll}
\hline Independent & $\mathrm{B}$ & $\operatorname{Exp}(\mathrm{B})$ & $\mathrm{p}$ \\
\hline Constant & -10.695 & & \\
Scientific experience of the head & 0.785 & 0.456 & 0.086 \\
Business experience of the head & -1.035 & 2.815 & 0.035 \\
Size & 0.026 & 1.027 & 0.031 \\
Technical sciences & 0.313 & 0.731 & 0.550 \\
Technical university & 0.730 & 0.482 & 0.195 \\
Vienna & -0.347 & 1.415 & 0.470 \\
Age & 0.307 & 1.360 & 0.439 \\
Age squared & -0.003 & 0.997 & 0.441 \\
N & 219 & & \\
Chi-square & 16.576 & & 0.035 \\
Log-likelihood & 150.866 & & \\
\hline
\end{tabular}

departments are able to convert ideas that can be commercialized. We thus also found support for hypothesis $2 b$.

The discipline and location of the university had no effect on the patent output either. However, we found that the age of the head of department had a negative significant effect and the size of the department a weak positive impact on the patent output. Technical universities were less likely to file patents. To check the robustness of the results we also conducted a logistic regression with a binary dependent variable (having patents or not), which delivered similar findings and confirmed our results. We assume that this result is mainly influenced by the case that many patentable inventions of technical universities do not emerge in pure university research but are generated in the context of collaborations with external industry partners as particularly technical universities are highly involved in applied research projects with companies (BMBWF 2018). However, for such collaborative research, Schibany et al. (2013) found that university researchers often perceive intellectual property right (IPR) regulations to be realized to the advantage of companies, since they are more experienced and have better negotiation power. Unsurprisingly, in the very same study some interviewed representatives of the technical universities raised fundamental concerns regarding IPRs and their importance. They concluded that IPRs for universities are overrated as only a few universities obtain substantial patent income, while most universities do not have the capacities, resources and infrastructure to commercialize patents successfully. Therefore, and contrary to past efforts, technical universities might have adapted their IPR strategies in the past and now allocate the filing of patents (and associated costs and risks) to their more experienced and apparently more demanding industrial partners while opting for other ways of compensation instead. For example, researchers very often only insist on their roles as inventors to promote their scientific career, while universities might settle for some kind of adjustment payment from their industrial partners to subrogate IPRs (Schibany et al. 2013). 


\subsection{Spin-offs}

To test hypotheses $3 \mathrm{a}$ and $3 \mathrm{~b}$ regarding the impact of business experience and scientific experience on the creation of spin-offs, we ran a logistic regression model measuring whether a department created one or more spin-offs or not. The statistics represented in Table 3 reveal that business experience of the heads of departments had-contrary to our proposition - $a$ negative effect on the generation of spin-offs $(b=-1.035)$. The scientific experience of the departments' heads in contrast had a positive impact $(b=0.785)$ although only significant on the $10 \%$ significance level. The size of the department showed a very weak effect and all other control variables indicated no results. Thus, we had to reject hypothesis 3 a but found some support for hypothesis $3 b$.

\section{Discussion and conclusion}

Entrepreneurial universities have to translate knowledge into economic activities (Etzkowitz 2016), they have to deliver on their third missions (Jones et al. 2013), foster relationships with industry and they have to integrate managerial and marketrelated practices and tools (Tijssen 2006). Similar to other areas in the public sector (see, for example, Poutanen and Kovalainen 2016), the adoption of business logic will impact the universities' habits of working, their structure, strategy and orientation. We assumed that leaders play a very crucial role in this transition. They are responsible for the implementation of changes (Peus et al. 2015) and serve as important role models in university - industry collaboration for their subordinate scientists (Rybnicek and Königsgruber 2019).

Our findings clearly show that academic leaders do not only influence the performance of individual researchers but also of entire research teams. This result contributes to the scant literature on the influence of leaders on objective team performance and is in line with Ceri-Booms et al.'s (2017) recent meta-analysis, which concludes that a single leader can directly enhance team output. At this point we argue that a leader's impact on team performance might be stronger in research teams like those investigated, compared to teams in other contexts. In general, leaders more strongly enhance others' performance when their tasks are rather complex, unstructured and offer room for individual task designment (Elkins and Keller 2003). As complexity, autonomy and reduced structure are common characteristics for describing the working conditions of research teams, the influence of academic leaders on their research team's output will be stronger than, for instance, the influence of production leaders on the output of their production team. Keller (2006) provides initial support for this assumption and shows that a leader's behaviour more strongly enhances the output quality of research teams compared to product development teams.

In the current study, we further demonstrate that the head of departments' experiences are important drivers for the entrepreneurial activities of an entire department. Figure 3 summarizes our results: while business experience of heads positively impacts the acquisition of third-party funds and the patent output of their departments, surprisingly it actually negatively influences the creation of spin-offs. The scientific experience of heads, in turn, does not impact the departments' acquisition 


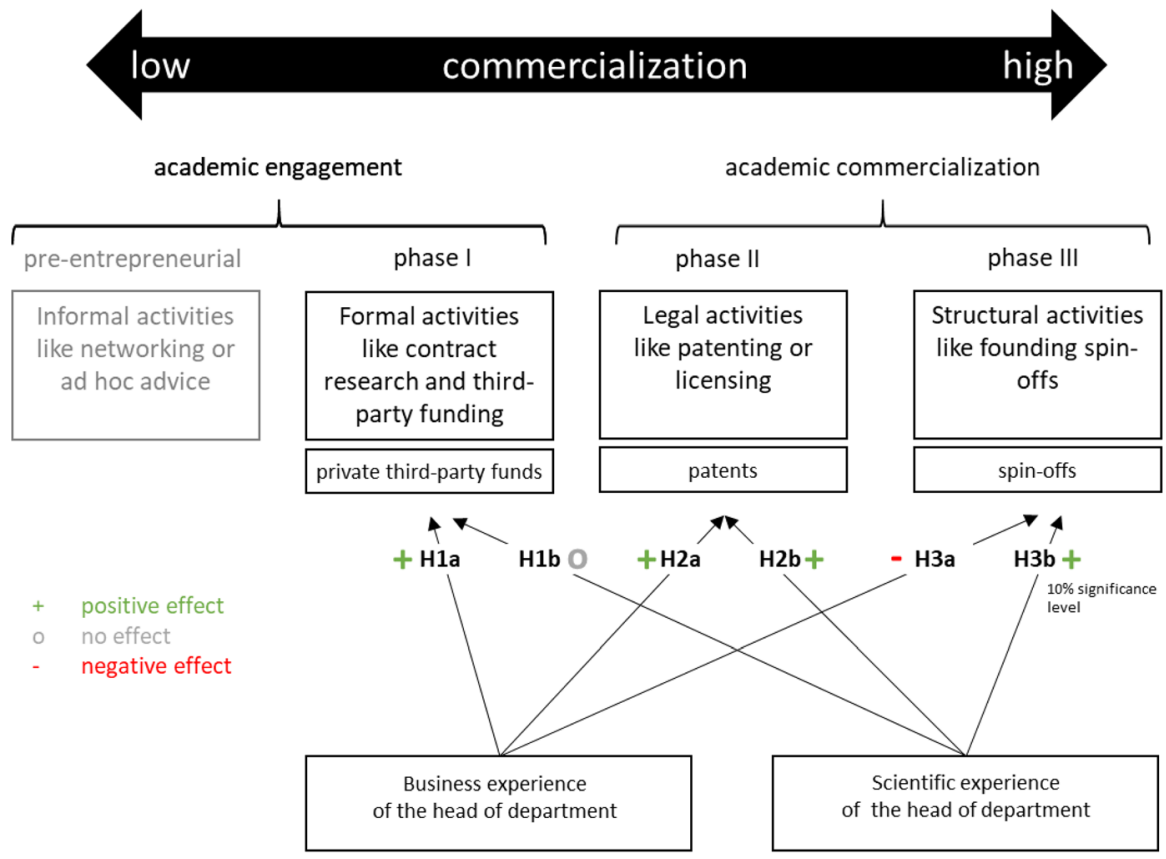

Fig. 3 Conceptual model and results

of third-party funds but positively influences the departments' patent output and, furthermore, the creation of spin-offs (although only by trend).

We suggest that leaders with such experiences are better equipped to join the interests of industrial partners with those of academic members to bridge the cultural gap between these very distinct areas. It is most likely that they earn more trust from their team members as they are believed to have an in-depth understanding of the needs of both industrial partners and academics. As shown by Braun et al. (2013) academic leaders are able to influence team and individual work outcome because they are trusted and are consequently accepted as role models. In conclusion, more experienced leaders are trusted more, which is why they are more influential than their less experienced colleagues.

When reviewing the summary of our results in Fig. 3, our study largely supported our assumptions and hypotheses with one relevant exception: we did not find evidence that business experience of heads positively impacts the creation of spin-offs. On the contrary, the effect was actually negative and thus somewhat surprising. We had assumed that the entry threshold to set foot in the business world by founding new ventures might be lower for departments with business-experienced heads. We offer two explanations for this unexpected finding:

The first explanation refers to the so-called Dunning-Kruger effect. Kruger and Dunning (1999) revealed a cognitive bias showing that people with lower abilities in a certain task have overly favourable views of their own abilities and are, as a consequence, more self-confident regarding their task performance. The very same deficits 
that lead them to make mistakes also nurture their inability to recognize those mistakes and acknowledge that their performance is poor (Dunning 2011). Many different studies on the Dunning-Kruger effect in diverse settings and environments have proven this effect and come to the same conclusion: that strong performers are more accurate in their judgement about success versus failure compared to their less competent peers (Dunning 2011). With regard to our result that the business experience of heads in fact negatively influences the creation of spin-offs, this could mean that, in accordance with our hypothesis, heads with prior business experience are indeed more competent regarding the establishment of spin-offs, yet they are also more accurate in judging their own or their teams' abilities as well as estimating the prospect of the commercial success of spin-offs than less experienced heads of departments. As a consequence, the more experienced heads might rather refrain from campaigning for the creation of spin-offs, which eventually results in the lower numbers of spin-offs registered in our data. In fact, this assumption receives support from entrepreneurship research. Although most literature favours the idea that entrepreneurial knowledge (e.g. through previous experiences or entrepreneurship training) positively impacts the attitude for founding a company (see, for example, the overview of factors influencing entrepreneurial intentions in Fayolle and Gailly 2015), there also exists contradictory evidence, namely that this knowledge can have negative consequences on entrepreneurial intentions too. In a highly cited study by Oosterbeek et al. (2010) it was shown that in leading entrepreneurship education programmes the effect on the intention to become an entrepreneur was in fact negative. The authors argue that those programmes may have helped students to develop a more realistic perspective on both what it takes to become an entrepreneur and on their own skills. In a similar vein, Fayolle and Gailly (2015) found that entrepreneurship programmes at universities increased the intention of those who initially had not planned an entrepreneurial career, but decreased that of participants who had initially planned one. They assume that the former rather perceived the positive dimensions, whereas the latter may have focused more on the limitations or challenges they had not seen till now. Summing up, it is not unlikely that department heads with previous business experiences also have a more realistic perspective on the existing competencies within the team, on the commercial potential of an invention and on the effort related to entrepreneurial activities. They might also better identify inherent limitations, problems and risks, which eventually reduces their optimism and their intention to establish a spin-off within the department.

The second explanation refers to experience-driven changes in motivation for career decisions (Chan and Drasgow 2001). Heads with previous business experiences most likely deliberately decided against a mere non-academic career. Their experience in business actually might have triggered their wish to leave business and transformed their primary work motivation-for instance, from wanting to achieve high income (calculative leadership motivation; Felfe and Schyns 2014) to wanting to find solutions for societal challenges (affective leadership motivation; Felfe and Schyns 2014). Once they take up their leading role at the university, they do not want to reverse or undermine their decision by founding or campaigning for a spin-off and thus going back to business again. However, we have not collected information on 
the motivation of the department heads, which is why further investigations are necessary to test this assumption in the future.

What implications can be drawn from our results? Taken together, in order to commercialize knowledge, scientists must have both the knowledge and the capability to commercialize it. While the former is presumably influenced by scientific experience, the latter is influenced by business experience. Therefore, if universities seek to foster their entrepreneurial ambitions and want to commercialize their knowledge more intensively, they might focus on their staff's business experiences. Subsequently, we introduce some recommendations that we derived from our results. These recommendations concern the universities' leader recruitment, their human resource development and their policies.

First, with regard to leader recruitment, our results overall suggest that researchers with previous business experiences from the private sector are very well equipped not only in creating new knowledge but also in commercializing it. Therefore, universities should consider actively asking for business experiences in the appointment of researchers and heads, respectively. Although, some universities already take this approach (Rybnicek et al. 2016), this request might be seen to be very controversial within the scientific community (please see the manifold critics regarding recent developments in the context of entrepreneurial universities in our theory section). Therefore, a very sensitive approach to balance scientific and business qualifications is necessary. Ultimately, universities are still research institutions. Furthermore, in recruitment processes, universities might also check how candidates' career motivation is influenced by their former business experiences. As already discussed, in the case where their former business experience has actually triggered their wish to leave industry and instead fostered their interest in academia, then their business experience will most likely not translate into the expected benefits.

Second, with regard to human resource development in general and leadership development in particular, universities might offer specific courses or programmes for their researchers to help them acquire additional business experiences and to understand the multiple roles of academic leaders as scientists, supervisors, network facilitators and entrepreneurs. As our results have shown, heads of departments do significantly influence the scientific and entrepreneurial performance of entire research teams. Therefore, to eventually fully exploit the teams' performance, sufficient awareness needs to be raised for the heads' diverse scientific and non-scientific tasks and roles. Even though this suggestion sounds fairly simple, the universities' ambitions in that regard might be undermined by the common thinking that academic leaders mainly need to be respected researchers in order to become good leaders. Moreover, leadership development programmes should also include networking activities. In particular, the conjoint programme participation of academic leaders and business leaders from outside the university might be advantageous. This setting allows academic leaders to learn from their business counterparts and might also help them to compensate for the lack of former business experience by enhancing their social networks, which are considered as vital to the commercialization of research (Dietz and Bozeman 2005).

Finally, with regard to the universities' policies, our findings might be used to promote changes in relevant rules, regulations and procedures. Universities might adjust their incentive schemes to enhance the researchers' motivation to obtain additional 
business experience. This could be done, for instance, by revising current university metrics (Etzkowitz 2016) and possibly allowing a reduction in publication output to be compensated with other metrics or by incentivizing sabbaticals for short-term working projects in the private industry. Such sabbaticals can help researchers to gain insights from industry about specific problems and stimulate research as well as entrepreneurial ideas (Bloedon and Stokes 1994). In this context, universities are also required to rethink their rules and guidelines regarding researchers having second jobs. Rigid limitations seem counterproductive to the idea of supporting staff in the acquisition of business experiences, while a too extensive industrial engagement might interfere with staff performance in research and teaching. Therefore, it might be necessary to more strongly consider the part-time employment of researchers to better enable the combination of scientific and non-scientific jobs, not only in the early stages of an academic career but also with professorships or other leading positions. Furthermore, it is advisable to strengthen those academic career paths that not only stipulate job changes within the university sector but also between sectors. Concretely, it must be avoided that work experience in non-scientific jobs has severe consequences on academic careers. On the contrary, it seems worthwhile stipulating intersectoral mobility through actively implementing those activities in academic career paths.

\section{Limitations}

When interpreting the results of this study one has to bear in mind its limitations. We focused our research on natural sciences, technical sciences and engineering as those disciplines are known to be a primary focus of academic commercialization and entrepreneurial efforts at universities (Subotzky 1999), and further report sufficient third-party income to allow statistical analyses (BMBWF 2018). Thus, our results might not be generalizable for other disciplines and further research is needed. With this paper we also have not studied possible moderating effects of university-specific factors, such as university policies, entrepreneurship education programmes, university services or specific university strategies, which may explain in more detail the discovered effects on the commercialization of research. However, all the universities studied have comparable prerequisites and conditions as they are all public universities and rely on very similar structures, strategies, services and policies. They were all driven by the Austrian education and research policy to develop and implement entrepreneurial strategies and corresponding services in the past decade. Thus, they have all established technology transfer offices and further services to promote the commercialization of research results according to these political requirements (see, for example, BMWFW and BMVIT 2016). However, we have not collected data on these activities and therefore cannot make a robust conclusion as to whether-despite similar basic conditions-university-specific activities or services influence the investigated variables or not. We also refrained from distinguishing the publications, either regarding the type of publication or regarding some quality-related criteria. This decision was based on methodological considerations proposed by Lin and Bozeman (2006), who conclude that eventually any kind of weighing is subjective and seems more appropriate for single-discipline studies. Moreover, we have excluded heads of departments who did not consistently carry out their position 
from 2013 to 2015, though this could have had an influence on our results. Furthermore, it was not possible to deal with dynamic effects. Such effects could occur, for instance, as more efficient researchers might more successfully acquire external funds, which further strengthen their capacity to publish and attract additional third-party funds. We have not considered experiences either in the public sector or in non-profit organizations, as we assume that entrepreneurial universities increasingly align with requirements, tools and skills more commonly associated with the private sector. However, future studies might investigate whether there are also significant effects for other sectors. We examined the assumed relationships over a 3-year period. As many departments are of a considerable size, with a number of researchers publishing and acquiring research funds simultaneously, we assume that the results are robust over time. In this context, we also ran some models with a time lag between the explanatory and dependent variable, which revealed no diverging results. However, time-lagged models might be used in future research to better deal with the reverse causality problem. Furthermore, studying different categories of funding streams in more detail might be worthwhile in a future study.

Acknowledgements Open access funding provided by University of Graz. We would like to express our gratitude to the Statistics Austria for their support in the analysis of data.

Open Access This article is licensed under a Creative Commons Attribution 4.0 International License, which permits use, sharing, adaptation, distribution and reproduction in any medium or format, as long as you give appropriate credit to the original author(s) and the source, provide a link to the Creative Commons licence, and indicate if changes were made. The images or other third party material in this article are included in the article's Creative Commons licence, unless indicated otherwise in a credit line to the material. If material is not included in the article's Creative Commons licence and your intended use is not permitted by statutory regulation or exceeds the permitted use, you will need to obtain permission directly from the copyright holder. To view a copy of this licence, visit http://creativecommons.org/licen ses/by/4.0/.

\section{Appendices}

\section{Appendix A - List of variables}

\begin{tabular}{|c|c|c|c|c|c|c|}
\hline Independent & Mean & s.d & $\min$ & $\max$ & source & Description \\
\hline $\begin{array}{l}\text { Scientific experience } \\
\text { of the head }\end{array}$ & 0.25 & 0.44 & 0 & 1 & research portal & $\begin{array}{l}\text { publications, mono- } \\
\text { graphs, edited books } \\
\text { and proceedings from } \\
2013-2015 \text { (top } \\
25 \%=1 \text { ) }\end{array}$ \\
\hline Patents & 1.32 & 3.91 & 0 & 34 & research portal & $\begin{array}{l}\text { number of patents from } \\
2013 \text { to } 2015\end{array}$ \\
\hline Spin-offs & 0.13 & 0.31 & 0 & 1 & interviews & $\begin{array}{l}\text { at least one spin-off cre- } \\
\text { ated at the department } \\
\text { between } 2013 \text { and } \\
2015\end{array}$ \\
\hline
\end{tabular}




\begin{tabular}{|c|c|c|c|c|c|c|}
\hline Independent & Mean & s.d & $\min$ & $\max$ & source & Description \\
\hline $\begin{array}{l}\text { Business experience of } \\
\text { the head }\end{array}$ & 0.47 & 0.49 & 0 & 1 & $\begin{array}{l}\mathrm{CV}, \text { com-mercial } \\
\text { register }\end{array}$ & $\begin{array}{l}\text { including private sector } \\
\text { experience on the CVs } \\
\text { (after master/diploma } \\
\text { degree) and functions } \\
\text { according to the } \\
\text { commercial register } \\
\text { (supervisory board, } \\
\text { owner, manager or } \\
\text { authorized representa- } \\
\text { tives of companies) } \\
\text { (excluding university } \\
\text { jobs, non-governmen- } \\
\text { tal organizations or } \\
\text { other public positions) }\end{array}$ \\
\hline Age & 55.05 & 7.20 & 38 & 75 & $\begin{array}{l}\mathrm{CV} \text {, commercial } \\
\text { register }\end{array}$ & $\begin{array}{l}\text { category personal data } \\
\text { or data from the com- } \\
\text { mercial register }\end{array}$ \\
\hline $\begin{array}{l}\text { Private third-party } \\
\text { funding }\end{array}$ & 0.25 & 0.43 & 0.00 & 1.00 & Statistics Austria & $\begin{array}{l}\text { data from } 2013 \text { to } 2015 \\
\quad(\text { top } 25 \%=1)\end{array}$ \\
\hline Size & 16.33 & 15.40 & 1.01 & 101.35 & Statistics Austria & $\begin{array}{l}\text { Number of research- } \\
\text { ers, data from } 2013 \\
\text { to } 2015\end{array}$ \\
\hline Technical sciences & 0.52 & 0.50 & 0 & 1 & Statistics Austria & $\begin{array}{l}52 \%(114) \text { of the } \\
\text { departments belong to } \\
\text { technical sciences and } \\
\text { engineering }\end{array}$ \\
\hline Vienna & 0.36 & 0.47 & 0 & 1 & Statistics Austria & $\begin{array}{l}3 \text { out of the } 10 \text { universi- } \\
\text { ties are located in } \\
\text { Vienna, } 79 \text { depart- } \\
\text { ments }(36 \%) \text { are part } \\
\text { of the } 3 \text { universities in } \\
\text { Vienna }\end{array}$ \\
\hline Technical university & 0.62 & 0.48 & 0 & 1 & Statistics Austria & $\begin{array}{l}3 \text { universities among } \\
\text { the } 10 \text { universities are } \\
\text { technical universi- } \\
\text { ties; } 135 \text { departments } \\
(62 \%) \text { belong to } \\
\text { one of the technical } \\
\text { universities }\end{array}$ \\
\hline
\end{tabular}




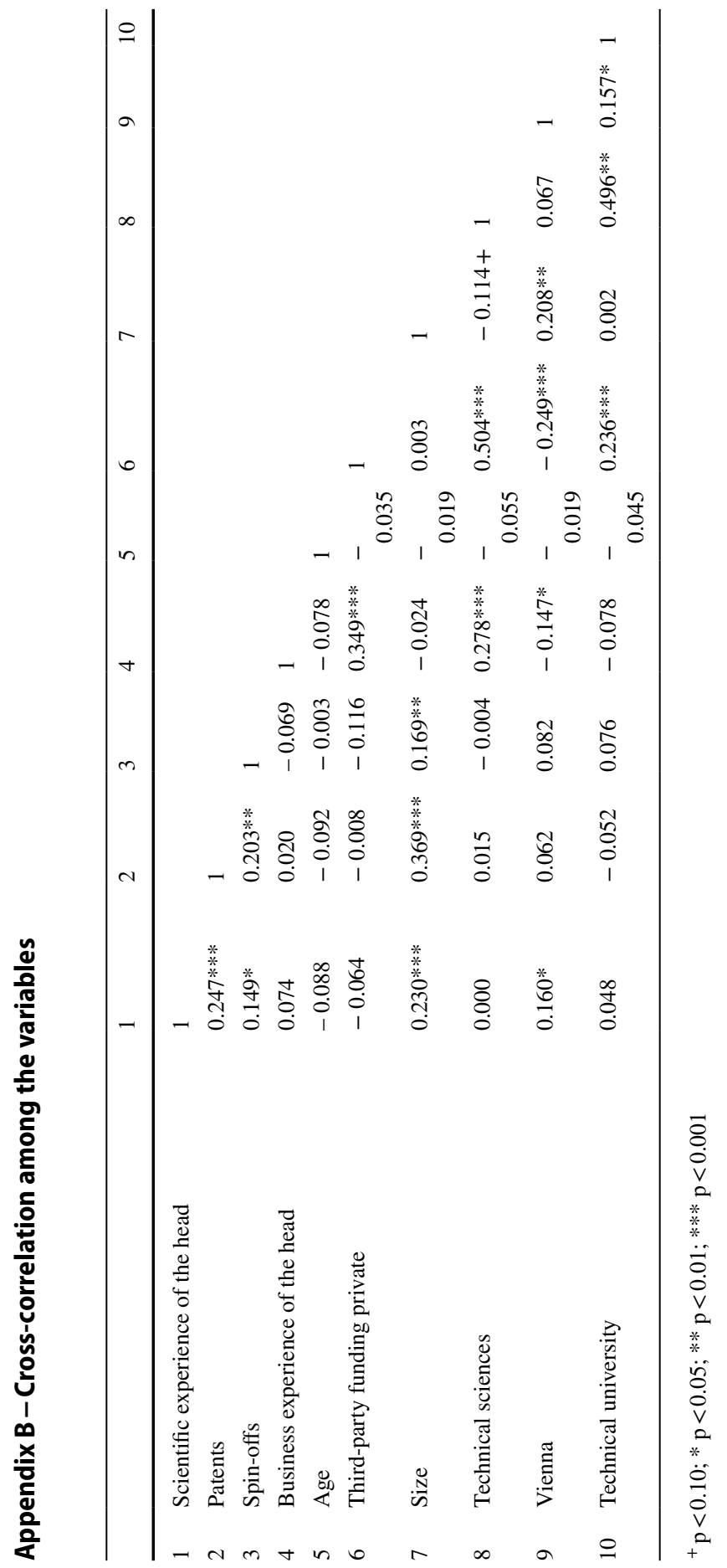




\section{References}

Aguillo IF, Bar-Ilan J, Levene M, Ortega JL (2010) Comparing university rankings. Scientometrics 85:243-256. https://doi.org/10.1007/s11192-010-0190-z

Armbruster C (2008) Research universities: autonomy and self-reliance after the entrepreneurial university. Policy Futures Educ 6:372-389. https://doi.org/10.2304/pfie.2008.6.4.372

Arundel A, Geuna A (2004) Proximity and the use of public science by innovative European firms. Econ Innovat New Technol 13:559-580. https://doi.org/10.1080/1043859092000234311

Bergner S (2015) Personale Führung an Universitäten. In: Gutschelhofer A, Rybnicek R, Raggautz A (eds) Universitäre Steuerung: Konzepte, Anwendungen und Trends für ein qualitatives Hochschulmanagement, Neue Ausg. Leykam, Graz, pp 221-233

Bloedon RV, Stokes DR (1994) Making university/industry collaborative research succeed. Res-Technol Manage 37:44-48. https://doi.org/10.1080/08956308.1994.11670969

BMBWF (2018) Universitätsbericht 2017. https://unidata.gv.at/SitePages/Publikationen.aspx. Accessed 28 Apr 2020

BMWFW, BMVIT (2016) Austrian research and technology report 2016. https://www.bmk.gv.at/dam/ jcr:a8e94297-7858-4ca7-b9f5-7ea85eb5959e/ftb_2016_en.pdf. Accessed 28 Apr 2020

Bolli T, Somogyi F (2011) Do competitively acquired funds induce universities to increase productivity? Res Policy 40:136-147. https://doi.org/10.1016/j.respol.2010.10.001

Braun S, Peus C, Weisweiler S, Frey D (2013) Transformational leadership, job satisfaction, and team performance: a multilevel mediation model of trust. Leadersh Q 24:270-283. https://doi. org/10.1016/j.leaqua.2012.11.006

Buela-Casal G, Gutiérrez-Martínez O, Bermúdez-Sánchez MP, Vadillo-Muñoz O (2007) Comparative study of international academic rankings of universities. Scientometrics 71:349-365. https://doi. org/10.1007/s11192-007-1653-8

Carayol N, Matt M (2006) Individual and collective determinants of academic scientists' productivity. Inf Econ Policy 18:55-72. https://doi.org/10.1016/j.infoecopol.2005.09.002

Ceri-Booms M, Curşeu PL, Oerlemans LAG (2017) Task and person-focused leadership behaviors and team performance: a meta-analysis. Hum Resour Manage Rev 27:178-192. https://doi. org/10.1016/j.hrmr.2016.09.010

Chan K-Y, Drasgow F (2001) Toward a theory of individual differences and leadership: understanding the motivation to lead. J Appl Psychol 86:481-498. https://doi.org/10.1037/0021-9010.86.3.481

Dietz JS, Bozeman B (2005) Academic careers, patents, and productivity: industry experience as scientific and technical human capital. Res Policy 34:349-367. https://doi.org/10.1016/j.respo 1.2005.01.008

Dragoni L, Oh I-S, Vankatwyk P, Tesluk PE (2011) Developing executive leaders: the relative contribution of cognitive ability, personality, and the accumulation of work experience in predicting strategic thinking competency. Pers Psychol 64:829-864. https://doi.org/10.1111/j.1744-6570.2011.01229.x

Dunning D (2011) The Dunning-Kruger effect. In: Olson JM, Zanna MP (eds) Advances in experimental social psychology, vol 44. Academic Press, San Diego, pp 247-296

Elia G, Secundo G, Passiante G (2017) Pathways towards the entrepreneurial university for creating entrepreneurial engineers: an Italian case. IJEIM 21:27-48. https://doi.org/10.1504/IJEIM.2017.10002349

Elkins T, Keller RT (2003) Leadership in research and development organizations: a literature review and conceptual framework. Leaders Q 14:587-606. https://doi.org/10.1016/S1048-9843(03)00053-5

Etzkowitz H (2003) Research groups as 'quasi-firms': the invention of the entrepreneurial university. Res Policy. https://doi.org/10.1016/S0048-7333(02)00009-4

Etzkowitz H (2016) The entrepreneurial university: Vision and metrics. Industry Higher Educ 30:83-97. https://doi.org/10.5367/ihe.2016.0303

Etzkowitz H, Leydesdorff L (2000) The dynamics of innovation: From National Systems and "Mode 2"' to a Triple Helix of university-industry-government relations. Res Policy. https://doi.org/10.1016/S0048 $-7333(99) 00055-4$

Etzkowitz H, Viale R (2010) Polyvalent knowledge and the entrepreneurial university: a third academic revolution? Crit Sociol 36:595-609. https://doi.org/10.1177/0896920510365921

Fabel O, Hein M, Hofmeister R (2008) Research productivity in business economics: an investigation of Austrian, German and Swiss universities. Ger Econ Rev 9:506-531. https://doi.org/10.111 $1 / \mathrm{j} .1468-0475.2008 .00450 . x$ 
Fayolle A, Gailly B (2015) The impact of entrepreneurship education on entrepreneurial attitudes and intention: Hysteresis and persistence. J Small Bus Manage 53:75-93. https://doi.org/10.1111/jsbm.12065

Felfe J, Schyns B (2014) Romance of leadership and motivation to lead. J Managerial Psych 29:850-865. https://doi.org/10.1108/JMP-03-2012-0076

Gabrielsson J, Politis D (2012) Work experience and the generation of new business ideas among entrepreneurs. Int J Ent Behav Res 18:48-74. https://doi.org/10.1108/13552551211201376

Goddard J, Robertson D, Vallance P (2012) Universities, technology and innovation centres and regional development: the case of the north-east of England. Camb J Econ 36:609-627. https://doi.org/10.1093/ cje/bes005

Gonzalez-Brambila C, Veloso F (2007) The determinants of research productivity: a study of Mexican researchers. Res Policy 36:1035-1051

Goodall AH (2006) Should top universities be led by top researchers and are they? J Doc 62:388-411. https:// doi.org/10.1108/00220410610666529

Goodall AH (2009) Highly cited leaders and the performance of research universities. Res Policy 38:10791092. https://doi.org/10.1016/j.respol.2009.04.002

Goodall AH, McDowell JM, Singell Jr. LD (2014) Leadership and the research productivity of university departments. https://ssrn.com/abstract=2385160. Accessed 6 Dec 2017

Gulbrandsen M, Smeby J-C (2005) Industry funding and university professors' research performance. Res Policy 34:932-950. https://doi.org/10.1016/j.respol.2005.05.004

Harvey J, Pettigrew A, Ferlie E (2002) The determinants of research group performance: Towards Mode 2? J od Manage Stud 39:22-2380. https://doi.org/10.1111/1467-6486.00310

Jones O, Macpherson A, Jayawarna D (2013) Resourcing the start-up business: creating dynamic entrepreneurial learning capabilities. Taylor and Francis, New York

Keller RT (2006) Transformational leadership, initiating structure, and substitutes for leadership: a longitudinal study of research and development project team performance. J Appl Psychol 91:202-210. https:// doi.org/10.1037/0021-9010.91.1.202

Kim PH, Aldrich HE, Keister LA (2006) Access (not) denied: the impact of financial, human, and cultural capital on entrepreneurial entry in the United States. Small Bus Econ 27:5-22. https://doi.org/10.1007/ s11187-006-0007-x

Kruger J, Dunning D (1999) Unskilled and unaware of it: How difficulties in recognizing one's own incompetence lead to inflated self-assessments. J Pers Soc Psychol 77:1121-1134

Lee YS (1996) 'Technology transfer' and the research university: a search for the boundaries of universityindustry collaboration. Res Policy 25:843-863. https://doi.org/10.1016/0048-7333(95)00857-8

Leisytë L, Kizniene D (2006) New public management in Lithuania's higher education. High Educ Policy 19:377-396. https://doi.org/10.1057/palgrave.hep.8300122

Lin M-W, Bozeman B (2006) Researchers' industry experience and productivity in university-industry research centers: a "Scientific and Technical Human Capital" explanation. J Technol Transf 31:269290. https://doi.org/10.1007/s10961-005-6111-2

Mintzberg H (1980) Structure in 5's: a synthesis of the research on organization design. Manage Sci 26:322-341

Oosterbeek H, van Praag M, Ijsselstein A (2010) The impact of entrepreneurship education on entrepreneurship skills and motivation. Eur Econ Rev 54:442-454. https://doi.org/10.1016/j.euroecorev.2009.08.002

Packham G, Jones P, Miller C, Pickernell D, Thomas B (2010) Attitudes towards entrepreneurship education: a comparative analysis. Educ Train 52:568-586. https://doi.org/10.1108/00400911011088926

Perkmann M, King Z, Pavelin S (2011) Engaging excellence?: Effects of faculty quality on university engagement with industry. Res Policy 40:539-552. https://doi.org/10.1016/j.respol.2011.01.007

Perkmann M, Tartari V, McKelvey M, Autio E, Broström A, D’Este P, Fini R, Geuna A, Grimaldi R, Hughes A, Krabel S, Kitson M, Llerena P, Lissoni F, Salter A, Sobrero M (2013) Academic engagement and commercialisation: a review of the literature on university-industry relations. Res Policy 42:423-442. https://doi.org/10.1016/j.respol.2012.09.007

Peus C, Welpe I, Weisweiler S, Frey D (2015) Führung an Hochschulen. In: Felfe J (ed) Trends der psychologischen Führungsforschung: Neue Konzepte, Methoden und Erkenntnisse. Hogrefe, Göttingen, pp 527-539

Pinheiro R, Langa PV, Pausits A (2015) One and two equals three?: The third mission of higher education institutions. Eur J High Educ 5:233-249. https://doi.org/10.1080/21568235.2015.1044552 
Poutanen S, Kovalainen A (2016) Professionalism and entrepreneurialism. In: Dent M, Bourgeault IL, Denis J-L, Kuhlmann E (eds) The Routledge companion to the professions and professionalism. Taylor and Francis, London, pp 116-128

Rybnicek R, Königsgruber R (2019) What makes industry-university collaboration succeed?: A systematic review of the literature. J Bus Econ 89:221-250. https://doi.org/10.1007/s11573-018-0916-6

Rybnicek R, Bergner S, Suk K (2016) Führung in Expertenorganisationen. In: Felfe J, van Dick R (eds) Handbuch Mitarbeiterführung. Springer, Berlin, pp 227-237

Schibany A, Dinges M, Reiner C, Reidl S, Hofer R, Marbler F, Leitner K-H, Dachs B, Zahradnik G, Weber M, Schartinger D, Edler J (2013) Ex-post Evaluierung der Kompetenzzentrenprogramme Kplus und K_ind/K_net. https://repository.fteval.at/96/

Secundo G, Schiuma G, Passiante G (2017) Entrepreneurial learning dynamics in knowledge-intensive enterprises. Int J Ent Behav Res 23:366-380. https://doi.org/10.1108/IJEBR-01-2017-0020

Shane S (2000) Prior knowledge and the discovery of entrepreneurial opportunities. Organ Sci 11:448-469. https://doi.org/10.1287/orsc.11.4.448.14602

Siegel DS, Waldman DA, Atwater LE, Link AN (2003) Commercial knowledge transfers from universities to firms: improving the effectiveness of university-industry collaboration. J High Technol Manage Res 14:111-133. https://doi.org/10.1016/S1047-8310(03)00007-5

Slaughter S, Leslie LL (2001) Expanding and elaborating the concept of academic capitalism. Organization 8:154-161. https://doi.org/10.1177/1350508401082003

Statistics Austria (2013) Österreichische Systematik der Wissenschaftszweige 2012. Accessed 28 Jan 2019

Statistics Austria (2017) Erhebung über Forschung und experimentelle Entwicklung (F\&E) im Hochschulsektor, im Sektor Staat, im privaten gemeinn. Sektor und im kooperativen Bereich 2002, 2004, 2006, 2007, 2009, 2011, 2013 und 2015

Subotzky G (1999) Alternatives to the entrepreneurial university: new modes of knowledge production in community service programs. High Educ 38:401-440. https://doi.org/10.1023/A:1003714528033

Tijssen RJW (2006) Universities and industrially relevant science: towards measurement models and indicators of entrepreneurial orientation. Res Policy 35:1569-1585. https://doi.org/10.1016/j.respo 1.2006.09.025

van Vught F (1999) Innovative universities. Tert Educ Manage 5:347-354. https://doi.org/10.1080/13583 883.1999.9967001

Zapkau FB, Schwens C, Steinmetz H, Kabst R (2015) Disentangling the effect of prior entrepreneurial exposure on entrepreneurial intention. J Bus Res 68:639-653. https://doi.org/10.1016/j.jbusres.2014.08.007

Ziman J (1995) Prometheus Bound: Science in a dynamic steady state. In: Johnston R (ed) Prometheus Bound: Science in a dynamic steady state by John Ziman. Cambridge University Press, Cambridge, $p$ ix +289

Zomer A, Benneworth P (2011) The rise of the university's third mission. In: Enders J, Boer HF, Westerheijden DF (eds) Reform of higher education in Europe. SensePublishers, Rotterdam, pp 81-103

Publisher's Note Springer Nature remains neutral with regard to jurisdictional claims in published maps and institutional affiliations. 